7. Reprod. Fert. (1967) 13, 189-197

\title{
D-MANNITOL, ERYTHRITOL AND GLYCEROL IN BOVINE SEMEN*
}

\author{
J. B. K. CLARK $\dagger$, E. F. GRAHAM, B. A. LEWIS $\$$ AND F. SMITH \\ Department of Animal Science, University of Minnesota, Minnesota, U.S.A.
}

(Received 17th June 1966, revised 13th September 1966)

Summary. An investigation into the distribution of freely occurring polyhydric alcohols in normal bovine semen has revealed the presence of three previously unreported constituents, namely D-mannitol $(17 \mathrm{mg} / 100 \mathrm{ml})$, erythritol $(6.9 \mathrm{mg} / 100 \mathrm{ml})$ and glycerol (circa $2 \mathrm{mg} / 100$ $\mathrm{ml}$ ). These three polyols, together with inositol and sorbitol were characterized by the preparation of suitable derivatives. Where applicable, the physical constants of the crystalline materials and of their derivatives were determined.

\section{INTRODUCTION}

Inositol, sorbitol (D-glucitol) and glycerylphosphorylcholine have already been identified in bovine seminal plasma (Hartree, 1957; King, Isherwood \& Mann, 1958; Kahane \& Levy, 1949; Dawson, Mann \& White, 1956). The present study provides evidence for the occurrence of a small amount of glycerol (circa $2 \mathrm{mg} / 100 \mathrm{ml}$ ) as well as of two other polyols: D-mannitol and erythritol.

\section{MATERIALS AND METHODS}

\section{Collection and processing of semen prior to analysis}

Three composite samples of bovine semen (samples I, II and III) were obtained from two sources, namely the Cooperative Breeding Organizations of Minnesota and Wisconsin and from a group of experimental bulls located at the University farm. All semen ejaculates were collected by artificial vagina. Immediately after collection, all semen ejaculates were pooled. Samples I and II were then placed in a water bath at $100^{\circ} \mathrm{C}$ for $2 \mathrm{~min}$. This treatment killed all the spermatozoa, and much of the heat-labile plasma protein was precipitated. After cooling, a volume of $95 \%$ ethanol equal to the total volume of the composite sample was added. This addition brought about further protein denaturation and precipitation. The semen was then placed in a cold room at $5^{\circ} \mathrm{C}$ until a sufficient volume had been accumulated. Sample I $(23.4 \mathrm{ml})$ was used in the tentative qualitative analysis of the carbohydrate fraction. Sample II $(111.7 \mathrm{ml})$ was used in the isolation and quantitative analysis of the polyols. Sample III $(46.0 \mathrm{ml})$ was used in the quantitative determination of glycerol by a colori-

* Scientific Journal Series Paper No. 5710, Minnesota Agricultural Experimental Station.

$\dagger$ Present address: Twyford Laboratories Ltd, Twyford Abbey Road, London, N.W.10.

$\$$ Department of Biochemistry.

$\S$ Deceased on 1st February 1965. 
metric technique. Sample IV $(910 \mathrm{ml})$ was later obtained from the Milk Marketing Board, Thames Ditton, Surrey, England. Neither sample III nor sample IV was subjected to heat treatment, but immediately after collection and pooling of the ejaculates a volume of cold $95 \%$ ethanol equal to the original semen volume was added. Further deproteinization of sample III was effected by the addition of 5 vol. $95 \%$ ethanol. After centrifugation, the supernatant was decanted and the precipitate subjected to repeated washing by centrifugation with $50 \%$ methanol. The supernatant solutions were then pooled.

\section{Isolation of carbohydrate fraction of seminal plasma before partition chromatography}

Before chromatographic techniques could be employed to detect and isolate the free carbohydrates in bovine semen, inorganic ions and amino acids were removed by passing the material through ion exchange columns. Complete removal of proteins from samples I, II and IV was effected by transferring the material to dialysis bags (Visking Co., Chicago, Illinois) and dialysing the contents against frequent changes of de-ionized and distilled water at $5^{\circ} \mathrm{C}$ until such time as the dialysate no longer gave a positive Molisch test; after every change of water, the surface of the water was layered with toluene. The dialysed, protein-free semen extract was concentrated in a rotary evaporator in vacuo, and the concentrated extract shaken gently with half a volume of diethyl ether in a separatory funnel. This was repeated three times. Deionization was effected by passing the protein and lipid-free material through columns containing Dowex $50\left(\mathrm{H}^{+}\right.$form) strong cation exchange resin (The Dow Chemical Co., Midland, Michigan) and then Duolite A $4\left(\mathrm{OH}^{-}\right.$form) weak anion exchange resin (Chemical Process Co., Redwood City, California). Frequently, the effluent collected from the anion exchange column was faintly alkaline due to 'bleeding' of the resin. In such a case it was neutralized on passing through a smaller column containing Amberlite IR120 $\left(\mathrm{H}^{+}\right.$form) strong cation exchange resin (Rohm and Hass Co., Philadelphia, Pennsylvania). Following de-ionization, the combined effluent and column washings were concentrated in a rotary evaporator in vacuo whereupon the $\mathrm{pH}$ of the carbohydrate fraction was checked with $\mathrm{pH}$ indicator paper as was also the presence or absence of amino acids by spraying a spot of the material on filter paper with ninhydrin reagent (Patton \& Chism, 1951). When de-ionization had been completed, the fraction was concentrated further in the rotary evaporator and then transferred to a high vacuum pump. The fraction was then taken to dryness and weighed.

\section{Alkaline oxidation of reducing carbohydrates}

The chromatographic resolution and detection of the polyols in bovine semen was greatly enhanced when part of the carbohydrate fraction of sample II, as prepared above but before de-ionization, was subjected to the procedure of alkaline oxidation (Smith \& Unrau, unpublished data). Reducing sugars, e.g. fructose, are oxidized by this procedure to glyconic and saccharinic acids which are easily removed by passing through columns containing ion exchange resins.

Sample II $(111.7 \mathrm{ml})$ yielded a fraction not de-ionized (after concentrating and drying) of $2.58 \mathrm{~g}$. This was redissolved in water and made up to $25.0 \mathrm{ml}$. 
An aliquot $(12.0 \mathrm{ml})$ of this solution was transferred to a round-bottomed flask (Sample II $=53.6 \mathrm{ml}$ ) and after addition of $3 \mathrm{ml} \mathrm{N}-\mathrm{NaOH}$ the mixture was heated for $4 \mathrm{hr}$ in a boiling water bath while aerating from a capillary within the flask. The alkalinity of the reaction mixture was maintained at $\mathrm{pH} 10$ or above by adding aliquots of the sodium hydroxide solution to neutralize the acids as they were formed. On completion of the reaction, the reaction mixture was passed successively through columns containing Amberlite IR $120\left(\mathrm{H}^{+}\right.$form) and Amberlite $401\left(\mathrm{OH}^{-}\right.$form) strong anion exchange resin. After the glyconic and saccharinic acids were removed the effluent contained only the nonreducing components.

A control experiment was subsequently carried out on $5.0 \mathrm{ml}$ of an aqueous solution containing D-fructose $(25.0 \mathrm{mg})$, sorbitol $(1.25 \mathrm{mg}), m$-inositol $(1.75 \mathrm{mg})$ and $\mathrm{L}-\alpha$-glycerylphosphorylcholine $(17.5 \mathrm{mg}$ ) (crystalline free diester, Sigma London Chemical Co., Ltd), which was subjected to the complete carbohydrate isolation procedure including heating, addition of ethanol, extraction with ether and alkaline oxidation. After removal of acids, the material was chromatographed using solvents $\mathrm{A}$ and $\mathrm{D}$. After spraying with ammoniacal silver nitrate and heating, both sorbitol and inositol as well as glycerol were clearly detected. Fructose and its degradation products had been completely removed. Neither mannitol nor erythritol could be detected. From the results of this experiment it was concluded that the isolation of glycerol could not be effected from a sample of semen which had undergone alkaline oxidation because of the possibility that its presence, and its concentration, might be artifacts arising from the degradation of glycerylphosphorylcholine. Hence it was considered necessary to characterize glycerol using an additional sample (sample IV, $910 \mathrm{ml}$ ) of bovine semen which was subjected to column partition chromatography after isolation of the carbohydrate fraction.

\section{Quantitative determination of fructose in sample $I I(111.7 \mathrm{ml})$}

An aliquot of the unoxidized portion of the carbohydrate fraction obtained from sample II containing a minimum of $0.3 \mathrm{mg}$ fructose was chromatographed on paper. The fructose band was located and excised as was a similar area from a blank chromatogram run concurrently. After elution with water, fructose was determined colorimetrically by the phenol-sulphuric acid method of Dubois, Gilles, Hamilton, Rebers \& Smith (1951, 1956). The fructose content of the semen was calculated after reference to a previously prepared standard curve.

\section{Paper partition chromatography}

Throughout this study only descending chromatography was employed. Whatman No. 1 paper was used for qualitative analyses and for quantitative separations of mixtures not exceeding a total of $10 \mathrm{mg}$ in weight. Recourse was had to Whatman No. 3MM paper for quantitative separations of mixtures up to a total of $75 \mathrm{mg}$. Four solvent systems were employed; A, Pyridine-ethyl acetate-water (1:2.5:3.5 v/v, upper phase), (Jermyn \& Isherwood, 1949; McFarren, Brand \& Rutkowski, 1951); B, n-Butanol-ethanol-water $(3: 2: 1 \mathrm{v} / \mathrm{v})$, (Whistler \& Duffy, 1955); C, n-Butanol-ethanol-water (4:1:5 v/v) (Partridge, 1946); and D, Butan-2-one-glacial acetic acid-saturated aqueous boric acid 
(9:1:1 v/v) (Rees \& Reynolds, 1958). The detection of carbohydrates with the silver spray in the presence of borate was made possible by treatment with a solution of $40 \%$ hydrogen fluoride ( 1 to $4 \mathrm{vol}$.) and acetone (40 vol.) before spraying with ammoniacal silver nitrate (Britton, 1959). Three spray reagents were employed: (i) ammoniacal silver nitrate (Partridge, 1948; Hough, 1950), (ii) p-anisidine (Briggs, Garner, Montgomery \& Smith, 1956; Christensen \& Smith, 1957) and (iii) anthrone (Johanson, 1953). This last proved a useful specific reagent for the detection of ketosugars both on chromatograms and in spot tests.

\section{Column partition chromatography of sample IV $(910 \mathrm{ml})$}

The methods of column chromatography employed were first described by Hough, Jones \& Wadman $(1948,1949)$. A tightly packed column of powdered cellulose (Whatman 'Chromedia' CC31), contained in a glass fractionating column $(85 \times 5 \mathrm{~cm})$, was used. The column was enclosed in a water jacket maintained at $30^{\circ} \mathrm{C}$ and was irrigated with solvent $\mathrm{B}$.

Approximately one half (circa $2.72 \mathrm{~g}$ ) of the carbohydrate fraction (circa $5.37 \mathrm{~g}$ ) obtained from sample IV, after dissolving in water to give a thin syrup, was introduced on to the column with a small transfer pipette and allowed to soak into the cellulose. A solvent reservoir was then placed in position. The eluate was collected in aliquots of circa $10 \mathrm{ml}$ by means of an automatic fractionating device (L.K.B. 'Radi Rac'). Small drops of eluate from every fifth tube were then placed in chronological order and chromatographed on paper. Appropriate aliquots of the eluate were then selected and combined. The solvent was removed by distillation in a rotary evaporator in vacuo. After tentative identification, the polyols isolated from samples IIa and IV were crystallized and/or their derivatives prepared as described below.

Identification of $\mathrm{m}$-inositol, D-mannitol, sorbitol and erythritol from sample IIa $(53.6 \mathrm{ml})$

The areas of the paper chromatogram corresponding to the various polyols were excised and eluted with water. The solutions were filtered through wads of cotton. The filtrates were heated with small quantities of activated charcoal ('Darco', Eastman Kodak Company) and were then filtered, while still hot, through wads of tightly packed cotton and the filtrates evaporated in vacuo to dryness. In order to identify these fractions attempts were made to induce crystal formation by the addition of a few drops of aqueous methanol. In all cases these were successful and recrystallizations of the products were effected from either aqueous methanol or aqueous ethanol.

The crystalline products obtained from the inositol and sorbitol fractions were acetylated by the sodium acetate-acetic anhydride method of Bates \& Associates (1942). Recrystallizations of the acetylated derivatives were effected from hot methanol. (A melting-point determination carried out on the crystalline product obtained from the 'sorbitol' fraction revealed that this was mannitol which had been separated by fractional crystallization. Attempts made to induce crystallization of the mother liquor failed. Both fractions were acetylated.)

The crystalline product obtained from the erythritol fraction was converted 
into the tetra- $p$-nitrobenzoate derivative prepared by dissolving the crystals in a small quantity $(1.0 \mathrm{ml})$ of dry pyridine, adding $p$-nitrobenzoyl chloride $\left(20 \%\right.$ molar excess) and heating at $80^{\circ} \mathrm{C}$ for $1 \mathrm{hr}$. Excess aroyl halide reagent was destroyed by the addition of a few drops of water to the cooled reaction mixture which was poured into a cold saturated solution of sodium bicarbonate and left overnight. The product was extracted with chloroform and anhydrous magnesium sulphate added. The solution was filtered and evaporated to dryness. The tetra- $p$-nitrobenzoate of erythritol was crystallized and recrystallized from a mixture of 1 part chloroform and 2 parts ethanol.

\section{Identification of glycerol separated by column chromatography of sample IV $(910 \mathrm{ml})$}

The product obtained after treatment with charcoal and decolorization of the fraction of the eluate corresponding to glycerol was a clear viscous syrup. The tri-p-nitrobenzoate derivative of glycerol was prepared as described previously. The product was crystallized and recrystallized from the chloroform ethanol mixture.

Quantitative determination of glycerol separated by paper chromatography of sample III $(46.0 \mathrm{ml})$

The concentration of free glycerol in this sample was determined colorimetrically by the method of periodate oxidation and the reaction of the formaldehyde liberated with chromotropic acid (Lambert \& Neish, 1950). The combined supernatants were evaporated to dryness in vacuo and the residue (934 mg) redissolved in water and made up to $5.0 \mathrm{ml}$ in a volumetric flask. An aliquot of this $(378 \mu \mathrm{l})$ was applied by micropipette to a chromatogram of Whatman No. 3MM paper. This was developed in solvent $B$ and the area corresponding to glycerol excised and eluted with water $(25.0 \mathrm{ml})$. A blank chromatogram was run concurrently and an area equal to that of the first was excised and treated in a similar manner. The eluates were filtered and 20.0 $\mathrm{ml}$ withdrawn from each and evaporated to dryness in round-bottomed flasks. These were taken up in minimal volumes of water and transferred to two $5.0 \mathrm{ml}$ volumetric flasks. The periodate oxidation of the contents was carried out in the manner prescribed, using $1 / 10$ the quantities of reagents.

The amount of glycerol present in the sample was calculated by reference to a previously prepared standard curve.

\section{RESULTS}

Preliminary qualitative chromatographic analyses of bovine semen had indicated the presence of several discrete spots, three of which corresponded with $m$-inositol, sorbitol and D-fructose. These have all been isolated previously by other workers (Hartree, 1957; King et al., 1958; Mann, 1954, 1946a, b, c).

Further analyses on paper performed on sample I revealed the presence of two additional components which moved faster than fructose but were present in very much lower concentrations as assessed visually by the area and intensity of their spots on spraying with ammoniacal silver nitrate. These components gave no reaction with $p$-anisidine, from which it was concluded that they were 
non-reducing and therefore probably polyols. These two unknown components corresponded to erythritol and glycerol.

Tentative identification of the various carbohydrate components in bovine semen was made by running aliquots of the carbohydrate fraction of sample I against authentic standard solutions in three different solvent systems A, B and C. Since D-fructose is the principal reducing sugar of bovine semen and since

\section{TABLE 1}

GHROMATOGRAPHIC MOBILITIES OF VARIOUS CARBOHYDRATE GOMPONENTS OF A COMPOSITE SAMPLE OF BOVINE SEMEN (SAMPLE I $=23.4 \mathrm{ml}$ ) AND OF STANDARD SOLUTIONS IN THREE DIFFERENT SOLVENT SYSTEMS (A, B AND C), IN RELATION TO THE MOBILITY OF FRUGTOSE $\left(R_{\mathrm{Fr}}=1\right)$

\begin{tabular}{|c|c|c|c|c|}
\hline \multirow{2}{*}{\multicolumn{2}{|c|}{ Material chromatographed }} & \multicolumn{3}{|c|}{ Solvent systems } \\
\hline & & $A$ & $B$ & $C$ \\
\hline \multicolumn{2}{|c|}{ Component $(C)-$ Standard $(S)$} & $C-S$ & $C-S$ & $C-S$ \\
\hline $\begin{array}{l}1 \\
2 \\
3 \\
4 \\
5 \\
6\end{array}$ & $\begin{array}{l}\text { - Inositol } \\
\text { - Sorbitol } \\
\text { - Mannitol* } \\
\text { - Fructose } \\
\text { - Erythritol } \\
\text { - Glycerol }\end{array}$ & $\begin{array}{l}0.21-0.21 \\
0.74-0.74 \\
0.77-0.77 \\
1.00-1.00 \\
1.35-1.35 \\
1.74-1.74\end{array}$ & $\begin{array}{l}0.23-0.23 \\
0.82-0.82 \\
0.87-0.87 \\
1.00-1.00 \\
1.53-1.53 \\
1.98-1.98\end{array}$ & $\begin{array}{l}0.13-0.13 \\
0.73-0.73 \\
0.75-0.75 \\
1.00-1.00 \\
1.75-1.75 \\
2.53-2.53\end{array}$ \\
\hline
\end{tabular}

* The chromatographic mobility values of mannitol are included here for reference. This polyol was not detected in the preliminary qualitative analyses and its presence was not revealed until it crystallized spontaneously from the 'sorbitol' fraction of sample II. Closer scrutiny of the spot corresponding to sorbitol revealed that it was slightly elongated in the direction of solvent flow and was therefore probably heterogeneous.

\section{TABLE 2}

CHROMATOGRAPHIC MOBILITIES OF DEGRADATION PRODUCTS FOLLOWING ALKALINE OXIDATION OF AN AQUEOUS SOLUTION CONTAINING $m$-INOSITOL, SORBITOL, D-FRUGTOSE AND L- $\alpha$-GLYGERYLPHOSPHORYLCHOLINE, AND STANDARD SOLUTIONS IN TWO DIFFERENT SOLVENT SYSTEMS (A AND D), IN RELATION TO THE MOBILITY OF FRUCTOSE $\left(R_{\mathrm{Fr}}=1\right)$

\begin{tabular}{cl|c|c}
\hline \multirow{2}{*}{ Material chromatographed } & \multicolumn{2}{|c}{ Solvent systems } \\
\cline { 2 - 3 } & & $A$ & $D$ \\
\hline Product $(P)$ & - Standard $(S)$ & $P-S$ & $P-S$ \\
\hline 1 & - Inositol & $0 \cdot 19-0 \cdot 19$ & $0 \cdot 09-0 \cdot 09$ \\
n.d. & - Mannitol & n.d.-0.69 & n.d.-1.47 \\
2 & - Sorbitol & $0 \cdot 71-0.71$ & $1 \cdot 68-1.68$ \\
n.d. & - Fructose & n.d.-1.00 & n.d.-1.00 \\
n.d. & - Erythritol & n.d.-1.41 & n.d.-2.85 \\
3 & - Glycerol & $1 \cdot 95-1.95$ & $3 \cdot 95-3.95$ \\
\hline
\end{tabular}

n.d., Non-detectable.

it appeared to move chromatographically at about half the rate of the fastest component, it was decided that in comparing the mobilities of the various components in the different solvent systems D-fructose would serve as a convenient reference $\left(R_{\mathrm{Fr}}=1 \cdot 0\right)$. The results of these studies are presented in 
Table 1. From the chromatographic evidence it was concluded that bovine semen contained the polyols erythritol and glycerol as well as inositol and sorbitol. The presence of D-mannitol as a constituent of normal bovine semen was not revealed in the initial chromatographic analyses.

The results of the control experiment, involving the alkaline oxidation of an aqueous solution of the components already known to occur in bovine semen, and in concentrations approximating those which have been reported in the literature are presented in Table 2. From the experimental evidence afforded

\section{TABLE 3}

QUANTITIES AND CONCENTRATIONS OF POLYOLS ISOLATED FROM A COMPOSITE SAMPLE (SAMPLE IIa $=53.6 \mathrm{ml}$ ) TOGETHER WITH THE PHYSICAL GONSTANTS OF THE CRYSTALLINE PRODUCTS AND OF THEIR DERIVATIVES

\begin{tabular}{|c|c|c|c|c|c|c|}
\hline Polyol & $\underset{(m g)}{Q u a n t i t y}$ & $\left|\begin{array}{l}\text { Concentration } \\
(\mathrm{mg} / 100 \mathrm{ml})\end{array}\right|$ & $\begin{array}{c}m . p . \text { and } \\
\text { m.m.p. }\left({ }^{\circ} \mathrm{C}\right)\end{array}$ & Derivatives & $\begin{array}{c}\text { m.p. and } \\
m . m . p .\left({ }^{\circ} \mathrm{C}\right)\end{array}$ & {$[\alpha]_{D}^{20}$} \\
\hline$m$-Inositol & $12 \cdot 7$ & $23 \cdot 7$ & 225 & Hexa-acetate & 218 to 219 & Inactive \\
\hline D-Mannitol & $9 \cdot 1$ & $17 \cdot 0$ & 165 to 166 & Hexa-acetate & 126 & $\begin{array}{c}+24 \cdot 6^{\circ} \\
\text { (concn. } 0.7 \text { in } \\
\text { CHCl }{ }_{3} \text { ) }\end{array}$ \\
\hline Sorbitol & $9 \cdot 0$ & $16 \cdot 8$ & $\begin{array}{c}\text { Not } \\
\text { crystallized }\end{array}$ & Hexa-acetate & 98 to 99 & $\begin{array}{c}+6 \cdot 7^{\circ} \\
\text { (concn. } 0.9 \text { in } \\
\mathrm{CHCl}_{3} \text { ) }\end{array}$ \\
\hline Erythritol & $3 \cdot 7$ & 6.9 & 119 to 120 & $\begin{array}{l}\text { Tetra- } p \text { - } \\
\text { nitrobenzoate }\end{array}$ & 239 & Inactive \\
\hline Glycerol* & $5 \cdot 4$ & ca. $2 \cdot 0$ & Syrup & $\begin{array}{l}\text { Tri-p- } \\
\text { nitrobenzoate }\end{array}$ & 195 to 196 & Inactive \\
\hline Glycerol $\dagger$ & - & 1.71 & & & & \\
\hline
\end{tabular}

A fructose determination carried out by the method of Dubois $e t$ al. $(1951,1956)$ on an unoxidized aliquot of the carbohydrate fraction of sample II gave $519 \mathrm{mg} / 100 \mathrm{ml}$.

* Obtained from column partition chromatography of sample IV $(910 \mathrm{ml})$.

+ Determined colorimetrically by the method of Lambert \& Neish (1950) on sample III.

by this control experiment it was concluded that the characterization of glycerol could not be effected in a sample of semen which had been subjected to alkaline oxidation (see 'Materials and Methods').

Table 3 summarizes the results obtained and the physical constants observed when the polyols, previously only tentatively identified, were characterized in sample IIa. The results reported in this table were confirmed when, in addition to glycerol, the other polyols identified were isolated and characterized in sample IV (910 ml) with results comparable to those reported below.

\section{DISGUSSION}

The isolation of inositol and sorbitol as constituents of normal bovine semen serves to confirm the findings of other workers in this field (Hartree, 1957; King et al., 1958). However, the isolation of D-mannitol, erythritol and free glycerol have been hitherto unreported in the literature, although the presence of 'bound' glycerol in the form of glycerylphosphorylcholine has been acknowledged. The experimental finding that both $\mathrm{D}$-mannitol and sorbitol are present 
in bovine semen in approximately equal concentrations does suggest that both D-mannitol and sorbitol may arise simultaneously from the reduction of D-fructose.

The isolation of erythritol as a constituent of normal bovine semen is of great interest. At the time of its isolation no mammalian tissue or fluid had been reported as containing this tetritol, although its presence has been reported in certain algae, lichens and grasses (Bamberger \& Landsiedl, 1900; Tischer, 1936 ; Hesse, 1861; Lindberg, 1955). In a report on the metabolism of the sugar alcohols and their derivatives, Carr \& Krantz (1945) expressed the opinion that erythritol and its two optically active isomers D- and L-threitol would be found to be refractory to metabolism by the animal body. This hypothesis was supported by Batt, Dickens \& Williamson (1960), who, during the course of a comprehensive study on tissue utilization of tetroses and tetritols, found that $\left[1-{ }^{14} \mathrm{C}\right]$ erythritol was not appreciably converted into ${ }^{14} \mathrm{CO}_{2}$ or ${ }^{14} \mathrm{C}$-glucose when incubated with slices of rat-liver tissue.

Among the first reports on the occurrence of erythritol in mammalian tissues is that of Touster, Hecht \& Todd (1960) who isolated erythritol in crystalline form from the urine of two fasting men and established its identity by chromatography, melting point and X-ray diffraction pattern; and Williams, Pearce \& Smith (1961) who isolated erythritol from bovine foetal tissue and prepared a crystalline derivative. This foetal product was found to be concentrated in the chorion, the allantoic fluid and the placental tissue. It was also found to stimulate the growth of the Brucella abortus organism.

Since this investigation was completed both erythritol and glycerol have been isolated from the semen of the domestic cock (Ahluwalia \& Graham, 1963). These observations as well as the absence of mannitol in fowl semen have been confirmed by Clark (unpublished data).

In the absence of experimental evidence it is largely a matter of conjecture as to what the site and mode of biosynthesis of these polyols may be, but their chemical nature might suggest that the hexose monophosphate oxidation shunt reactions may play a more important role in the metabolism of the genital tract accessory glands and their secretions than has hitherto been realized.

\section{ACKNOWLEDGMENTS}

One of us (J.B.K.C.) wishes to thank the Cooperative Breeding Organizations of Minnesota and Wisconsin for financial and other assistance granted in the pursuit of these studies. He is also indebted to Mr Geoffrey F. Smith, M.R.c.v.s., Head, Veterinary Division, Milk Marketing Board, Thames Ditton, Surrey, for his cooperation in obtaining additional samples of bovine semen.

\section{REFERENCES}

Ahluwalia, B. S. \& Graham, E. F. (1963) Some biochemical aspects of fowl semen. (Abstract). Poultry Sci. 42, 1251.

Bamberger, M. \& Landsiedl, A. (1900) Erythrit in Trentepohlia jolithus. Mh. Chem. 21, 571.

Bates, F. J. \& Associates (1942) Sodium acetate method of acetylation. Polarimetry, saccharimetry and the sugars. Circ. U.S. natn. Bur. Stand. C440, 488.

Batt, R. D., Dickens, F. \& Williamson, D. H. (1960) Tetrose metabolism. II. The utilization of tetroses and tetritols by rat tissue. Biochem. . . 77, 281. 
Briggs, D. R., Garner, E. F., Montgomery, R. \& Smith, F. (1956) Analysis of mixtures of D-glucose and D-mannose by paper electrophoresis. Analyt. Chem. 28, 1333.

BRitton, H. G. (1959) The detection of carbohydrates with silver in the presence of borate. Biochem. $\mathcal{J}$. 73, $19 \mathrm{P}$.

Carr, C. J. \& Krantz, J. C. (1945) Metabolism of the sugar alcohols and their derivatives. Adv. Carbohyd. Chem. 1, 175.

Christensen, G. M. \& Smith, F. (1957) The constitution of a wheat starch dextrin. 7. Am. chem. Soc. 79, 4492.

Dawson, R. M. C., Mann, T. \& Whrte, I. G. (1956) Glycerylphosphorylcholine and phosphorylcholine in semen and their relation to choline. Biochem. 7. 65, 627.

Dubois, M., Gilles, K., Hamilton, J. K., Rebers, P. A. \& Smith, F. (1951) A colorimetric method for the determination of sugars. Nature, Lond. 168, 167.

Dubois, M., Gilles, K., Hamilton, J. K., Rebers, P. A. \& Smith, F. (1956) Colorimetric method for determination of sugars and related substances. Analyt. Chem. 28, 350.

Hartree, E. F. (1957) Inositol in seminal plasma. Biochem. 7. 66, 131.

Hesse, O. (1861) Untersuchungen aus dem chemischen Laboratorium in Greifswald. Justus Liebigs Annln Chem. 117, 297.

Hough, L. (1950) Application of paper chromatography to the separation of the polyhydric alcohols. Nature, Lond. 165, 400.

Hough, L., Jones, J. K. N. \& Wadman, W. H. (1948) Application of paper partition chromatography to the separation of the sugars and their methylated derivatives on a column of powdered cellulose. Nature, Lond. 162, 448.

Hough, L., JonEs, J. K. N. \& WADMAN, W. H. (1949) Quantitative analysis of mixtures of sugars by the method of partition chromatography. IV. The separation of the sugars and their methylated derivatives on columns of powdered cellulose. . chem. Soc. 2511.

JeRmyn, M. A. \& Isherwood, F. A. (1949) Improved separation of sugars on the paper partition chromatogram. Biochem. 7. 44, 402.

Johanson, R. (1953) New specific reagent for keto sugars. Nature, Lond. 172, 956.

Kahane, E. \& Levy, J. (1949) Revue physiologique. La choline chez les êtres vivants. J. Physiol., Paris, 41, 183.

King, T. E., Isherwood, F. A. \& Mann, T. (1958) Sorbitol in semen. Abstracts of 4th int. Congr. Biochem. Vienna, p. 77.

LAMBert, M. \& Neish, A. C. (1950) Rapid method for estimation of glycerol in fermentation solutions Can. J. Res. 20B, 83.

Lindberg, B. (1955) Studies on the chemistry of lichens. VIII. Investigation of a Dermatocarpon and some Rocella species. Acta chem. scand. 9, 917.

MANN, T. (1946a) The origin and function of seminal fructose. Biochem. 7. 40, xxix.

Mann, T. (1946b) Studies on the metabolism of semen. III. Fructose as a normal constituent of seminal plasma. Site of formation and function of fructose in semen. Biochem. 7. 40, 481.

Mann, T. (1946c) Fructose, a constituent of semen. Nature, Lond. 157, 79.

MANN, T. (1954) On the presence and role of inositol and certain other substances in the seminal vesicle secretion of the boar. Proc. $R$. Soc. B, 142, 21.

McFarRen, E. F., BRAND, K. \& RutKowski, H. R. (1951) Quantitative determination of sugars on filter paper chromatograms by direct photometry. Analyt. Chem. 23, 1146.

Partridge, S. M. (1946) Application of the paper partition chromatogram to the quantitative analysis of reducing sugars. Nature, Lond. 158, 270.

Partridge, S. M. (1948) Filter paper partition chromatography of sugars. Biochem. 7. 42, 238.

Patron, A. R. \& Ghism, P. (1951) Quantitative paper chromatography of amino acids. Analyt. Chem. 23, 1683.

ReEs, W. R. \& REYnolds, T. (1958) A solvent for the chromatographic separation of glucose and sorbitol. Nature, Lond. 181, 767.

Tischer, J. (1936) Uber die Carotinoide und die Bildung von Jonon in Trentepohlia, nebst Bermerkungen über den Gehalt dieser Alge an Erythrit. Hoppe-Seyler's Z. physiol. Chem. 243, 103.

Touster, O., Hecht, S. O. \& TodD, W. M. (1960) The isolation of crystalline erythritol from normal human urine. F. biol. Chem. 235, 951.

Whistler, R. \& DufFy, J. H. (1955) Maltopentaose and crystalline octadeca-O-acetylmaltopentaitol. 7. Am. chem. Soc. 77, 1017.

Williams, A. E., Pearce, J. H. \& Smith, H. (1961) Erythritol in bovine foetal tissue. Biochem. 7. 81, $5 P$. 